\title{
PEMANFAATAN LIMBAH PEMBANGKIT LISTRIK TENAGA UAP (PLTU) NAGAN RAYA SEBAGAI BAHAN STABILISASI TANAH EKSPANSIF
}

\author{
Muhammad Zardi ${ }^{1}$, Meliyana ${ }^{2}$ \\ ${ }^{1,2}$ Program Studi Teknik Sipil Universitas Abulyatama \\ Jl. Blang Bintang Lama Km. 8,5 Lampoh Keudee Aceh Besar \\ email:mr_zardi@yahoo.com,yana_meli@yahoo.com
}

\begin{abstract}
Abstrak: Tanah ekspansif adalah tanah yang kandungan lempungnya memiliki potensi kembang susut akibat perubahan kadar air. Kondisi jalan pada ruas jalan Ie Mirah-Lama Muda (Kabupaten Aceh Barat Daya) mengalami hal yang sama, yaitu cepat mengalami kerusakan meskipun sering dilakukan perbaikan pada lapisan permukaan (surfase). Tujuan dari penelitian ini adalah untuk mengetahui apakah fly ash yang berasal dari PLTU Nagan Raya layak dijadikan bahan stabilisasi untuk proyek-proyek jalan pada tanah ekspansif khususnya ruas jalan lintas barat Aceh. Metode yang dilakukan adalah dengan melakukan stabilisasi tanah dengan menambah Fly Ash dan melakukan pengujian di Laboratorium Pengujian yang dilakukan adalah analisis kadar air, analisis saringan, analisis berat jenis, pengujian batas attenberg, analisis CBR dan pemadatan standar proctor. Hasil dari uji laboratorium menunjukkan adanya penurunan berat jenis sampel tanah disebabkan karena tanah distabilisasi dengan fly ash yang memiliki berat jenis yang lebih kecil. Hasil dari penambahan Fly Ash menurunkan kadar air dalam campuran tanah. Hal ini sangat menguntungkan dalam proses stabilisasi karena potensi pengembangan tanah semakin berkurang. Hasil test Attenberg menunjukkan penambahan Fly Ash 20\% mampu menurunkan nilai indeks plastisitas dari 28,61\% menjadi 2,88\%. Hal ini terjadi karena penambahan Fly Ash menyebabkan terjadinya ikatan antar partikel dan tertutupnya sebagian pori-pori tanah sehingga tanah menjadi kurang sensitif terhadap perubahan kadar air. Penambahan Fly Ash meningkatkan berat isi kering karena terjadi perubahan distribusi butiran halus menjadi tanah berbutir kasar sesuai banyaknya penambahan Fly Ash. Penambahan fly Ash 20\% memberikan peningkatan yang cukup signifikan dengan nilai CBR sebesar $15,7 \%$ dibandingkan daya dukung tanah asli yang hanya memiliki nilai CBR 3.4\% dan tergolong tanah yang jelek. Fly Ash yang berasal dari PLTU Nagan Raya layak untuk dijadikan bahan stabilisasi tanah dalam pelaksanaan konstruksi khususnya jalan raya yaitu sebagai subbase course
\end{abstract}

Keywords : stabilisasi, fly ash, sub grade, tanah ekspansif.

Pada konstruksi jalan, kekuatan atau kekokohannya ditentukan oleh kualitas tanah asli sebagai bahan dasar (subgrade). Jika tanah asli mempunyai daya dukung (kepadatan kering, CBR) rendah, maka konstruksi jalan akan cepat mengalami kerusakan. Penyebab lain dari kerusakan jalana dalah perilaku tanah dasar yang bersifat ekspansif. Tanah ekspansif adalah tanah yang kandungan lempungnya memiliki potensi kembang susut akibat perubahan kadar air.

Kondisi jalan pada ruas lintas barat Aceh juga mengalami hal yang sama, yaitu cepat mengalami kerusakan meskipun sering dilakukan perbaikan pada permukaan (lap surfase). Pada ruas jalan lintas barat Aceh ditemukan penurunan tanah dasar, retak pada badan jalan, jalan yang berlubang dan bergelombang. Kondisi ini sangat mengganggu kenyamanan berlalu lintas. Hal 
ini terjadi diakibatkan karena tanah sub-grade yang tidak stabil memiliki nilai CBR rendah. Retak pada perkerasan dapat terjadi akibat penyusutan maupun pengembangan tanah. Retak yang terjadi berupa retak memanjang yang dimuai dari bahu jalan menuju ke tengah perkerasan.

Untuk mengatasi permasalahan tersebut salah satu cara atau metode yang dipergunakan adalah memperbaiki kualitas tanah asli dengan stabilisasi. Metode stabilisasi yang akan digunakan peneliti adalah stabilisasi tanah sub-grade dengan menggunakan limbah hasil dari pembakaran pada PLTU Nagan Raya yaitu Fly Ash.

\section{KAJIAN PUSTAKA}

\section{Identifikasi Tanah Ekspansif}

Tanah dengan karakter ekspansif ditemukan pada jenis tanah lempung (clay). Tanah lempung dapat diidentifikasi berdasarkan ukuran partikel, indeks plastisitas, batas cair dan kandungan mineral. ASTM mensyaratkan lebih dari 50\% lolos saringan No.200 (0,075mm) dengan indeks plastisitas minimum $35 \%$.

Tabel 1. Potensi Pengembangan Berbagai Nilai Indeks Plastisitas Menurut Chen (1975)

\begin{tabular}{|c|c|}
\hline $\begin{array}{c}\text { Indeks } \\
\text { Plastisitas } \\
\text { (PI) }\end{array}$ & $\begin{array}{c}\text { Potensi } \\
\text { Pengembangan }\end{array}$ \\
\hline $0-15$ & Rendah \\
\hline $10-20$ & Sedang \\
\hline $20-35$ & Tinggi \\
\hline$>35$ & Sangat Tinggi \\
\hline
\end{tabular}

Sumber : Chen, 1975
Tabel 2. Potensi Pengembangan Berbagai Nilai Indeks Plastisitas Menurut William dan Donaldson (1980).

\begin{tabular}{|c|c|}
\hline $\begin{array}{c}\text { Indeks } \\
\text { Plastisitas (PI) }\end{array}$ & $\begin{array}{c}\text { Potensi } \\
\text { Pengembangan }\end{array}$ \\
\hline$<12$ & Rendah \\
\hline $12-24$ & Sedang \\
\hline $24-32$ & Tinggi \\
\hline$>32$ & Sangat Tinggi \\
\hline
\end{tabular}

Sumber : William dan Donaldson (1980) dalam J.E Gillott (1987:183)

Holtz and Gibbs, (1956) menyusun suatu indentifikasi tentang kriteria tingkat ekspansif suatu tanah yang dikemudian disempurnakan oleh Chen (1975) yang peneliti kutip dalam Yang Fang. H (1991:310) seperti pada tabel berikut.

Tabel 3. Kemungkinan Perubahan Volume Tanah Ekspansif

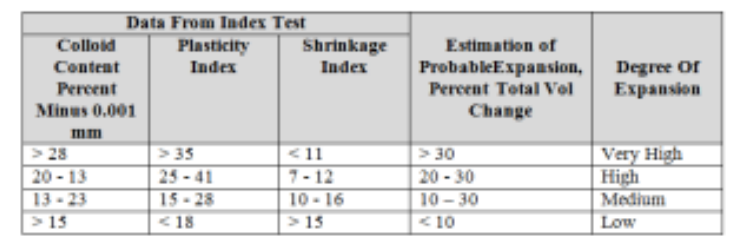

Sumber : Holtz and Gibbs, (1956), dalam Yang Fang. H (1991:310)

Menurut Raman (1967) yang disadur peneliti dari Anonim (2006:9), potensi pengembangan dapat diidentifkasi berdasarkan tabel berikut.

Tabel 4. Potensi Pengembangan Tanah

\begin{tabular}{|c|c|c|}
\hline $\begin{array}{c}\text { PI } \\
(\boldsymbol{\%})\end{array}$ & $\begin{array}{c}\text { SI } \\
(\boldsymbol{\%})\end{array}$ & $\begin{array}{c}\text { Potensi } \\
\text { Pengembangan }\end{array}$ \\
\hline$<12$ & $<15$ & Rendah \\
\hline $12-$ & $13-$ & Sedang \\
23 & 50 & \\
\hline $23-$ & $30-$ & Tinggi \\
32 & 40 & \\
\hline$>32$ & $>40$ & Sangat Tinggi \\
\hline
\end{tabular}

Sumber : Raman (1967) dalam Anonim (2006:9)

Volume 3, No. 1, Januari 2017 
Untuk memudahkan identifikasi tanah ekspansif berdasarkan tingkat kembang-susut tanah, Holtz dan Gibss (1965) yang peneliti sadur dari Dakshanamurthy V. (1973:98) mengembangkan grafik hubungan indeks plastisitas, liquid limit dan batas susut untuk mendapatkan tingkat pengembangan tanah. Semakin besar indeks plastisitas dan liquid limit maka semakin besar potensi kembang susut tanah. Grafik potensi ekspansif tanah dapat dilihat pada gambar berikut.

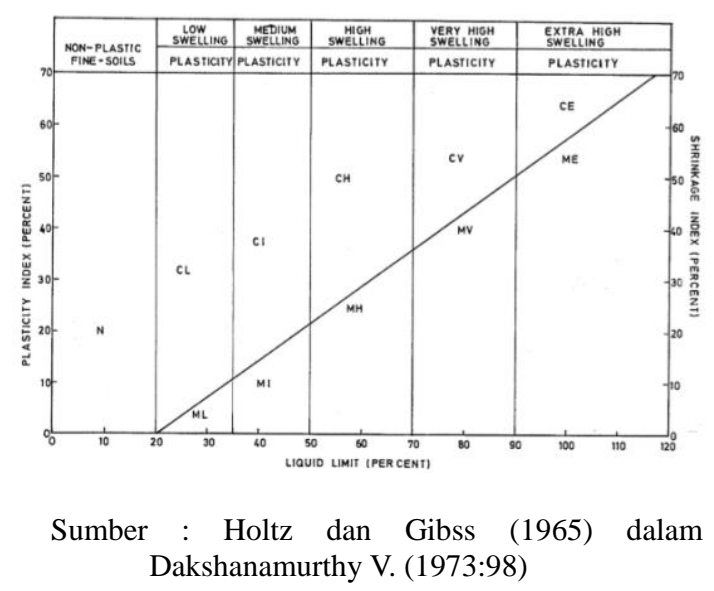

Gambar 1. Grafik Potensi Ekspansif Tanah

\section{Stabilisasi dengan Fly Ash}

Fly ash merupakan material yang memiliki ukuran butiran yang halus, berwarna keabu-abuan dan diperoleh dari hasil pembakaran batu bara. Pada intinya fly ash mengandung unsur kimia antara lain silika ( $\mathrm{SiO} 2)$, alumina (Al2O3), fero oksida (Fe2O3) dan kalsium oksida $(\mathrm{CaO})$, juga mengandung unsur tambahan lain yaitu magnesium oksida (MgO), titanium oksida (TiO2), alkalin ( $\mathrm{Na2O}$ dan $\mathrm{K} 2 \mathrm{O}$ ), sulfur trioksida (SO3), pospor oksida (P2O5) dan carbon.

\section{Daya Dukung Tanah}

Kriteria yang dipakai untuk menilai memuaskan atau tidaknya stabilisasi, didasarkan faktor kekuatan dengan menggunakan parameter kepadatan kering maksimum $(\gamma \mathrm{d})$ dan CBR, swelling. CBR merupakan ukuran daya dukung tanah yang dipadatkan dengan daya pemadatan tertentu dan kadar air tertentu dibandingkan dengan beban standard pada batu pecah. Dengan demikian, besaran CBR adalah persentase atau perbandingan daya dukung tanah yang diteliti dan daya dukung batu pecah standar pada nilai penetrasi yang sama $(0,1$ inch dan 0,2 inch).

\section{Pengujian-Pengujian Tanah}

Bowles (1993:39) menyebutkan dalam menentukan klasifikasi tanah diperlukan data dari sifat-sifat fisis tanah seperti batas cair, batas plastis, berat jenis dan analisa saringan.

\section{Pemeriksaan berat jenis (ASTM D854)}

Berat jenis adalah perbandingan antara berat volume butiran padat dengan berat volume air pada temperatur $\mathrm{t}^{0} \mathrm{C}$.

$$
\mathrm{Gs}=\frac{\gamma s}{\gamma w}
$$

Dimana :

$\gamma s=$ berat volume butiran padat

$\gamma w=$ berat volume air

\section{Batas Cair dan Batas Plastis}

Selisih antara batas cair dan batas plastis ialah daerah dimana tanah tersebut adalah dalam keadaan plastis. Ini disebut "Indeks Plastisitas"(PI), yaitu: 
$\mathrm{PI}=\mathrm{LL}-\mathrm{PL}$

Dimana:

$\mathrm{PI}=$ indeks plastisitas, $(\%)$

$\mathrm{LL}=$ batas cair, $(\%)$

$\mathrm{PL}=$ batas plastis, $(\%)$

\section{Pemadatan Tanah}

Bowles (1993:206) menyatakan bahwa pemadatan merupakan usaha untuk mempertinggi kerapan tanah dengan memakai energi mekanis untuk menghasilkan pemampatan partikel. Keuntungan yang diperoleh dari pemadatan adalah berkurangnya angka pori dan bertambahnya kekuatan tanah.

Kepadatan tanah biasanya diukur dengan menentukan berat isi kering, adapun rumus berat isi kering $(\gamma \mathrm{d})$ adalah:

$$
\begin{aligned}
& \gamma_{\mathrm{d}}=\frac{\gamma w e t}{(1+w)} \\
& \gamma_{\text {wet }}=\frac{B}{V}
\end{aligned}
$$

Dimana:

$$
\begin{aligned}
& \mathrm{w}=\text { kadar air }(\%) \\
& \gamma_{\text {wet }}=\text { berat isi basah }\left(\mathrm{gram} / \mathrm{cm}^{3}\right) \\
& \mathrm{B}=\text { berat benda uji }(\mathrm{gram}) \\
& \mathrm{V}=\text { isi cetakan }\left(\mathrm{cm}^{3}\right)
\end{aligned}
$$

\section{METODE PENELITIAN}

Adapun metodologi yang dilakukan dalam penelitian ini adalah dengan urutan sebagai berikut :

1. Pekerjaan persiapan, berupa pencarian literatur tentang tanah ekspansif, metode stabilisasi tanah, melakukan persiapan peralatan dan penyusunan rencana mobilisasi ke lapangan.

2. Pengambilan sampel tanah (sampling) dengan menggunakan sampel tanah terganggu (disturbed soil) dengan membuang top soil setebal $50 \mathrm{~cm}$ pada ruas jalan Ie Mirah-Lama Muda Kabupaten Aceh Barat Daya.

3. Pengujian laboratorium, untuk mengetahui nilai index properties dan engineering properties tanah.

4. Analisa data laboratorium, untuk mengetahui perubahan yang terjadi pada tanah sebelum distabilisasi dengan fly ash dan sesudah distabilisasi.

5. Pelaporan Hasil Penelitian

\section{Pengambilan Sampel Tanah}

Sampel tanah yang akan diambil berasal dari ruas jalan Ie-Mirah - Lama Muda, Kecamatan Babah Rot Kabupaten Aceh Barat Daya. Sampel tanah yang akan diambil berapa pada KM. 2+000 dari jalan negara menuju Lama Muda.

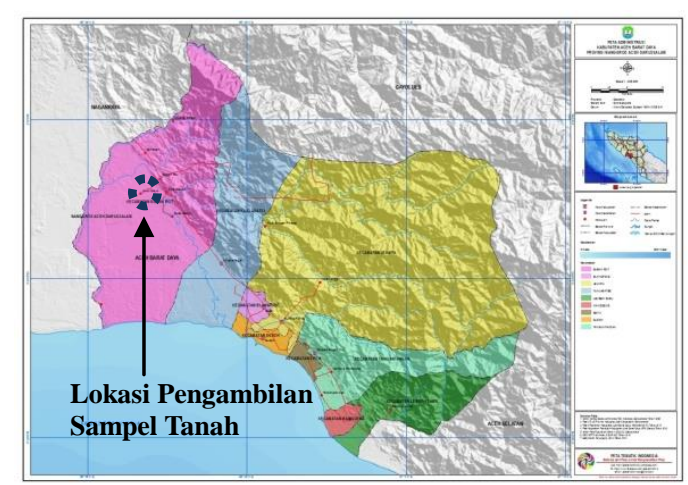

Sumber : Bappeda Kabupaten Aceh Barat Daya (2010)

Gambar 2. Peta Lokasi Pengambilan Sampel Tanah dalam Lingkup Kabupaten Aceh Barat Daya, Provinsi Aceh

Sampel fly ash diambil dari PLTU Nagan Raya yang berada di Jalan Meulaboh - Tapaktuan, Kuala Pesisir Kabupaten Nagan 
raya. Fly Ash ini merupakan hasil buangan dari proses pembakaran

\section{Pengujian Laboratorium}

Dalam pelaksanaan penelitian ini ada beberapa tahapan yang harus dilakukan oleh peneliti untuk mempermudah dalam pelaksanaan pengujian, diantarnya pengamatan visual terhadap sampel, pengukuran serta analisis data. Pengujian ini dilakukan untuk mengetahui data kerakteristik sifat fisik tanah asli atau disebut propertis tanah asli sifat fisik tanah yang telah diberi bahan tambahan berupa Fly Ash.

\section{Persiapan Material}

Mempersiapkan bahan yang digunakan dalam melakukan pengujian ini berupa tanah lempung yang telah dikeringkan dengan melakukan penjemuran dibawah sinar matahari dan diayak dengan menggunakan saringan No.4. Bahan campurannya adalah Fly Ash batu bara yang didapatkan di PLTU Nagan Raya.

Tabel 5. Variasi Campuran dan Jumlah Penambahan Fly Ash

\begin{tabular}{|c|l|c|l|}
\hline No. & Variasi Campuran & Kode Sampel & $\begin{array}{l}\text { Jumlah } \\
\text { Bahan } \\
\text { Tambahan } \\
(\text { Fly Ash })\end{array}$ \\
\hline 1 & Tanah Asli & TA & $\begin{array}{l}\text { Tanpa bahan } \\
\text { tambahan }\end{array}$ \\
\hline 2 & $\begin{array}{l}\text { Tanah Asli + Fly } \\
\text { Ash 10\% }\end{array}$ & FA 10 & $\begin{array}{l}10 \% \text { x berat } \\
\text { tanah kering }\end{array}$ \\
\hline 3 & $\begin{array}{l}\text { Tanah Asli + Fly } \\
\text { Ash 15\% }\end{array}$ & FA 15 & $\begin{array}{l}15 \% \text { x berat } \\
\text { tanah kering }\end{array}$ \\
\hline 4 & $\begin{array}{l}\text { Tanah Asli + Fly } \\
\text { Ash 20\% }\end{array}$ & FA 20 & $\begin{array}{l}20 \% \text { x berat } \\
\text { tanah kering }\end{array}$ \\
\hline
\end{tabular}

\section{Pengujian Sifat Fisis}

Pengujian sifat fisis pada tanah asli tanpa diberi penambahan campuran untuk mengetahui karakteristik tanah asli yang digunakan dalam penelitian ini, pengujiannya meliputi:

1. Pengujian analisa saringan (ASTM D2478)

Pengujian analisa saringan ini bertujuan untuk menentukan jenis tanah yang diteliti.

2. Pengujian konsistensi tanah (ASTM 4318)

Pemeriksaan konsistensi tanah ini terdiri dari pengujian batas cair, batas plastis dan indeks plastisitas.

3. Pengujian berat jenis (ASTM D854)

Pengujian berat jenis ini dilakukan pada tanah asli untuk mengetahui berat jenis tanah yang sedang diteliti.

4. Pengujian pemadatan standar (ASTM D698)

Pengujian pemadatan standar dilakukan untuk mengetahui kadar air optimum (OMC) dan berat isi kering maksimum (d maks).

5. Pengujiaan daya dukung tanah (CBR) (ASTM D1883)

Pengujian CBR dilakukan untuk mengetahui daya dukung tanah asli yang diteliti. 


\section{HASIL DAN PEMBAHASAN}

\section{Identifikasi tanah asli}

Identifikasi ditujukan untuk mengetahui jenis tanah dan apakah sampel tanah termasuk tanah ekspansif atau tidak. Tanah asli memiliki Indeks Plastisitas sebesar 28,61.

1. Menurut Chen (1975), Tanah asli dengan IP $=28,61$ termasuk tanah ekspansif (memiliki potensi pengembangan) yang tinggi.

2. Menurut William dan Donaldson (1980), tanah dengan Indeks Plastisitas IP $=28,61$ akan memiliki potensi pengembangan yang tinggi.

3. Menurut Grafik Potensi Ekspansif Tanah (Holtz dan Gibss, 1965) : Tanah asli memiliki tingkat plastisitas sangat tinggi.

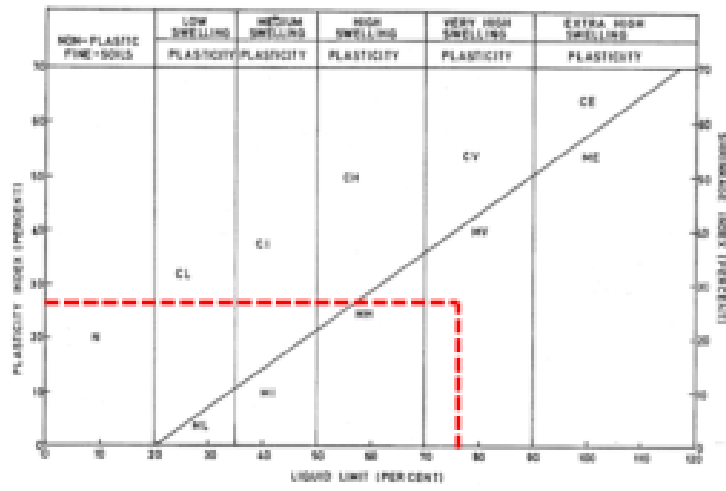

Gambar 3. Grafik Hasil Penentuan Tingkat Plastisitas Tanah Asli

Dengan demikian tanah asli dapat dikategorikan sebagai tanah ekspansif dengan kategori sangat tinggi.
Pengaruh Penambahan Fly Ash pada

\section{Tanah Ekspansif Terhadap Kadar Air}

Tingkat pengembangan tanah ekspansif sangat tergantung dari kadar air awal (initial water content) yang terdapat dalam tanah. Penambahan Fly Ash menurunkan kadar air dalam campuran tanah. Hal ini sangat menguntungkan dalam proses stabilisasi karena potensi pengembangan tanah semakin berkurang. Disamping itu sifat dari Fly Ash yang hampir sama dengan semen dimana Fly Ash mengikat butiran tanah sehingga menjadi padat.

Tabel 6. Hasil Test Kadar Air dengan Penambahan Fly Ash

\begin{tabular}{|l|r|}
\hline \multicolumn{1}{|c|}{ Stabilisasi } & Kadar Air (\%) \\
\hline Tanah Asli & 50.37 \\
\hline Tanah Asli + Fly Ash 10\% & 30,05 \\
\hline Tanah Asli + Fly Ash 15\% & 23,12 \\
\hline Tanah Asli + Fly Ash 20\% & 17,26 \\
\hline
\end{tabular}

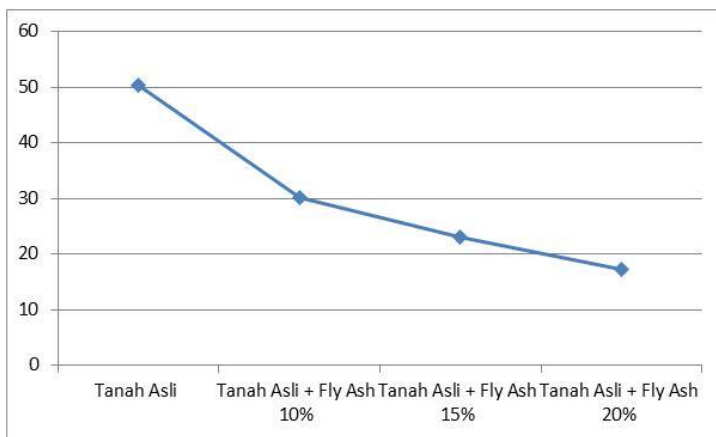

Gambar 4. Grafik Pengaruh Penambahan Fly Ash pada Tanah Ekspansif Terhadap Kadar Air

\section{Pengaruh Penambahan Fly Ash pada}

\section{Tanah Ekspansif Terhadap Batas}

\section{Attenberg}

Hasil test Attenberg menunjukkan bahwa sampel yang dicampur dengan Fly Ash mengalami penurunan indeks plastisitas dibandingkan dengan tanah asli. Hal ini 
terjadi karena penambahan Fly Ash menyebabkan terjadinya ikatan antar partikel dan tertutupnya sebagian pori-pori tanah sehingga tanah menjadi kurang sensitif terhadap perubahan kadar air. Ikatan antar partikel ini menyebabkan terbentuknya agregat yang lebih besar sehingga menurunkan nilai batas cair tanah. Penambahan Fly Ash memberikan pengaruh yang besar terhadap penurunan nilai Liquid Limit (LL), Plastic Limit (PL) dan Indeks Plastisitas.

Untuk lebih jelasnya mengenai hasil dari penambahan Fly Ash Terhadap Batas Attenberg dapat dilihat pada tabel dan gambar berikut.

Tabel 7. Hasil Test Attenberg dengan Penambahan Fly Ash

\begin{tabular}{|l|r|r|r|}
\hline \multirow{2}{*}{ Stabilisasi } & \multicolumn{3}{|c|}{ Nilai Attenberg (\%) } \\
\cline { 2 - 4 } & \multicolumn{1}{|c|}{ LL } & \multicolumn{1}{|c|}{ PL } & \multicolumn{1}{c|}{ IP } \\
\hline Tanah Asli & 77,7 & 49,09 & 28,61 \\
\hline Tanah Asli +10\% Fly Ash & 55,04 & 40,08 & 14,96 \\
\hline Tanah Asli + 15\% Fly Ash & 38,98 & 30,01 & 8,97 \\
\hline Tanah Asli + 20\% Fly Ash & 28,9 & 26,02 & 2,88 \\
\hline
\end{tabular}

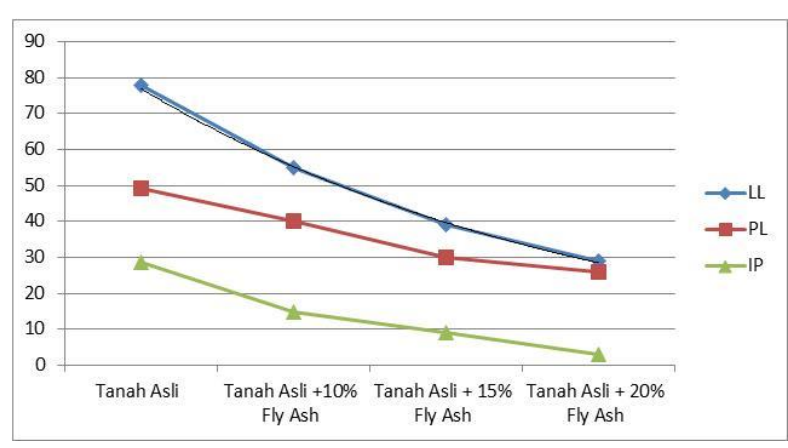

Gambar 5. Grafik Pengaruh Penambahan Fly Ash pada Tanah Ekspansif Terhadap Batas Attenberg
Pengaruh Penambahan Fly Ash pada Tanah Ekspansif Terhadap Berat Jenis

\section{/Berat Spesifik}

Dari hasil stabilisasi tanah asli ekspansif dengan dengan penambahan Fly Ash terlihat adanya penurunan Spesific Gravity. Hal ini disebabkan karena berat jenis Fly Ash lebih rendah dari dibandingkan dengan nilai berat jenis tanah asli. Berat jenis Fly Ash berkisar antara 1,9 sampai dengan 2,5. Selain itu proses sementasi pada tanah dan Fly Ash menyebabkan perekatan antar partikel, rongga-rongga yang telah ada sebagian akan diselimuti bahan Fly Ash.

Tabel 8. Hasil Test Berat Spesifik/Berat Jenis (Gs) dengan Penambahan Fly Ash

\begin{tabular}{|l|r|}
\hline \multicolumn{1}{|c|}{ Stabilisasi } & Berat Jenis (Gs) \\
\hline Tanah Asli & 2,77 \\
\hline Tanah Asli + Fly Ash 10\% & 2,71 \\
\hline Tanah Asli + Fly Ash 15\% & 2,62 \\
\hline Tanah Asli + Fly Ash $20 \%$ & 1,54 \\
\hline
\end{tabular}

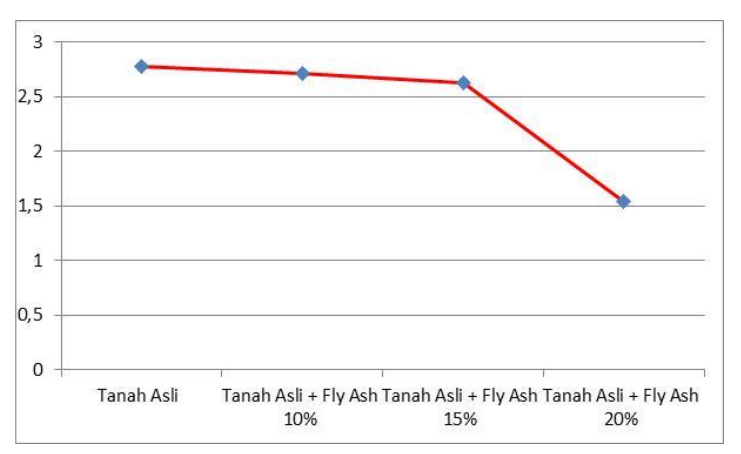

Gambar 6. Grafik Pengaruh Penambahan Fly Ash pada Tanah Ekspansif Terhadap Berat Jenis

\section{Pengaruh Penambahan Fly Ash pada}

\section{Tanah Ekspansif Terhadap Kepadatan}

Penambahan Fly Ash meningkatkan berat isi kering karena terjadi perubahan distribusi butiran halus menjadi tanah berbutir kasar sesuai banyaknya penambahan Fly Ash. Pemadatan pada tanah adalah proses 
memperkecil ruangan pori dengan menggunakan beban dinamis yang dipengaruhi oleh mekanisme pergerakan dari partikel padatnya. Pada setiap standar pemadatan yang digunakan akan diperoleh nilai kadar air optimum (optimum moisture content) yang menghasilkan kepadatan maksimum (berat volume kering maksimum).

Penambahan Fly Ash pada tanah ekspansif menyebabkan berkurangnya sifat kompresibilitas (mudah mampat), berkurangnya permeabilitas, dan berkurangnya volume sebagai akibat perubahan kadar air.

Tabel 9. Hasil Test Standar Proctor dengan Penambahan Fly Ash

\begin{tabular}{|l|r|r|}
\hline \multicolumn{1}{|c|}{ Stabilisasi } & \multicolumn{1}{c|}{ Wopt (\%) } & \multicolumn{2}{c|}{$\boldsymbol{\gamma}$ maks } \\
\hline Tanah Asli & 33,1 & 1,28 \\
\hline Tanah Asli + Fly Ash 10\% & 20,13 & 1,32 \\
\hline Tanah Asli + Fly Ash 15\% & 17,11 & 1,42 \\
\hline Tanah Asli + Fly Ash 20\% & 14,9 & 1,54 \\
\hline
\end{tabular}

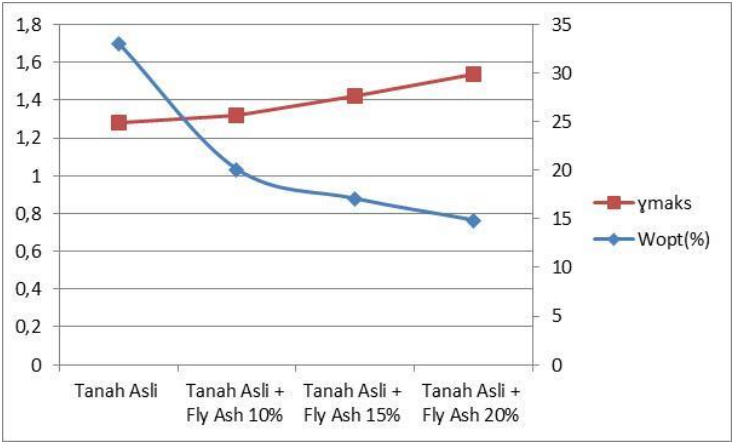

Gambar 7. Grafik Pengaruh Penambahan Fly Ash pada Tanah Ekspansif Terhadap Kepadatan
Pengaruh Penambahan Fly Ash pada Tanah Ekspansif Terhadap Daya Dukung (CBR)

Penambahan fly ash memberikan peningkatan yang cukup signifikan terhadap daya dukung tanah. Tanah asli yang hanya memiliki nilai CBR 3.4\% dan tergolong tanah yang jelek, jika tanah ini digunakan untuk konstruksi maka harus distabilisasi. Penambahan fly ash sampai dengan 20\% ternyata dapat meningkatkan daya dukung tanah. Pada penambahan fly ash sebesar 10\% belum memperlihat peningkatan daya dukung. Untuk lebih jelasnya mengenai peningkatan nilai CBR seiring dengan penambahan fly ash dapat dilihat pada tabel berikut.

Tabel 10. Hasil Pengujian Daya Dukung Tanah (CBR) dengan Penambahan Fly Ash

\begin{tabular}{|l|r|}
\hline \multicolumn{1}{|c|}{ Stabilisasi } & \multicolumn{1}{|c|}{ CBR (\%) } \\
\hline Tanah Asli & 5,42 \\
\hline Tanah Asli + Fly Ash 10\% & 8,96 \\
\hline Tanah Asli + Fly Ash 15\% & 15,7 \\
\hline Tanah Asli + Fly Ash 20\% &
\end{tabular}

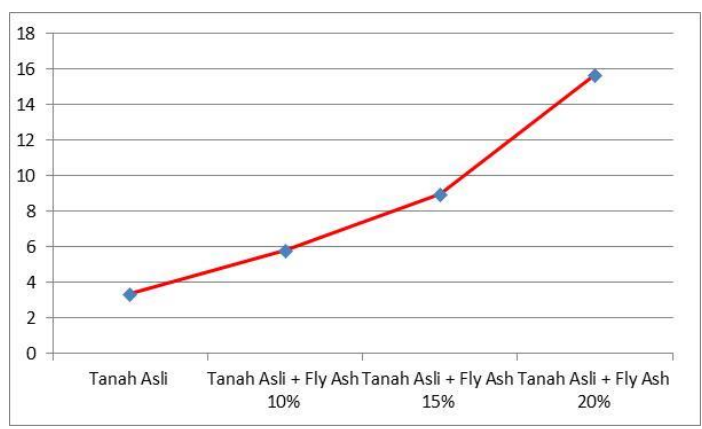

Gambar 8. Grafik Pengaruh Penambahan Fly Ash pada Tanah Ekspansif Terhadap Daya Dukung Tanah 


\section{KESIMPULANDAN SARAN}

\section{Kesimpulan}

1. Berdasarkan identifikasi, jenis tanah asli merupakan tanah ekspansif.

2. Penambahan Fly Ash sebesar $20 \%$ pada tanah asli mampu menurunkan kadar air dalam campuran tanah dari $50,37 \%$ menjadi $17,26 \%$. Hal ini sangat menguntungkan dalam proses stabilisasi karena potensi pengembangan tanah semakin berkurang.

3. Hasil test Attenberg menunjukkan bahwa sampel yang dicampur dengan Fly Ash mengalami penurunan indeks plastisitas dibandingkan dengan tanah asli. Penambahan Fly Ash 20\% mampu menurunkan nilai indeks plastisitas dari $28,61 \%$ menjadi $2,88 \%$ sehingga tanah sudah tidak memiliki potensi pengembangan yang tinggi Hal ini terjadi karena penambahan Fly Ash menyebabkan terjadinya ikatan antar partikel dan tertutupnya sebagian poripori tanah sehingga tanah menjadi kurang sensitif terhadap perubahan kadar air.

4. Penambahan Fly Ash 20\% memperlihatkan adanya penurunan Spesific Gravity dari 2,77 menjadi 1,54. Hal ini disebabkan karena berat jenis Fly Ash lebih rendah dari dibandingkan dengan nilai berat jenis tanah asli.

5. Penambahan Fly Ash sebesar $20 \%$ pada tanah ekspansif menyebabkan berkurangnya sifat kompresibilitas (mudah mampat), berkurangnya permeabilitas, dan berkurangnya volume sebagai akibat perubahan kadar air.

6. Penambahan fly Ash $20 \%$ memberikan peningkatan yang cukup signifikan dengan nilai CBR sebesar 15,7\% dibandingkan daya dukung tanah asli yang hanya memiliki nilai CBR $3.4 \%$ dan tergolong tanah yang jelek.

7. Fly Ash yang berasal dari PLTU Nagan Raya layak untuk dijadikan bahan stabilisasi tanah dalam pelaksanaan konstruksi khususnya jalan raya. Tanah yang telah distabilisasi dengan $20 \%$ fly ash hanya dapat digunakan sebagai sub base bukan base course karena memiliki CBR sebesar 15,7\%. Peraturan Bina Marga mensyaratkan untuk Base Course $\mathrm{CBR} \geq 50 \%$.

\section{Saran}

1. Perlu dilakukan penelitian lain dengan menggunakan bahan stabilisasi jenis lain agar dapat diketahui mana bahan stabilisasi yang lebih efektif digunakan khususnya dalam konstruksi jalan raya

2. Dari pelaksanaan laboratorium peneliti belum menjadikan variasi kadar air sebagai variabel dalam menilai daya dukung tanah. Untuk penelitian lainnya variasi kadar air perlu juga untuk ditinjau.

3. Penggunaan fly ash sebagai bahan stabilisasi tentunya perlu mendapat perhatian khusus.

\section{DAFTAR PUSTAKA}

ASTM. (1997). Annual Book Of ASTM Standards, Volume 04.08 Soil and 
Rock, First Edition.

Badan Litbang PU Departemen Pekerjaan Umum. (2006). RSNI 2006 Pd T10-2005-B. Penanganan Tanah Ekspansif Untuk Konstruksi Jalan. Jakarta

Bowles, J.E. (1993). Sifat-Sifat Fisis dan Geoteknis Tanah (Mekanika Tanah). Jakarta: Penerbit Erlangga, Jakarta.

CHEN, F.H. (1975). Foundation on Expansive Soil, Development in Geotechnical Engineering

Amsterdam: Esevier Scientific

Publishing Company,

Chomaedhi., et. al. (2007). Kajian Tanah

Ekspansif, Jalan Akses Jembatan

Suramadu Sisi Madura. Jurnal Aplikasi, 3(1), 11-15.

I. Yilmaz. (2004), Relationships between Liquid Limit, Cation Exchange Capacity, and Swelling Potentials of Clayey Soils, Eurasian Soil Science, 37(5), 506-512.

J.E Gillott. (1987). Clay in Engineering Geology. Amerika: Elsevier Science Publishing Company Inc,.

Karimah, M.A. (2014). Pengaruh Penambahan Bahan Campuran Dengan Komposisi 75\% Fly Ash dan 25\% Slag Baja Pada Tanah Lempung Ekspansif Terhadap Nilai CBR dan Swelling. Jurnal Mahasiswa Universitas Brawijaya, 1(2), 277-285.

Sudjianto, A.T., et.al. (2011). The Effect of Water Content Change and Variation Suction in Behavior Swelling of Expansive Soil. International Journal of Civil \& Environmental Engineering IJCEEIJENS, 11(3), 11-17.

Sulistyowati, T. (2006). Pengaruh Stabilisasi Tanah Lempung Ekspansif Dengan Fly Ash Terhadap Nilai Daya Dukung CBR. e-Journal FT UNRAM, 2(1), April 2006, 77-83.

V. Dakshanamurthy dan V. Raman. (1973). A Simple Method of Identifying an Expansive Soil. Journal Soil and Foundation, 13(1), Maret 1973, 96-101.

Wesley, L.D. (1977). Mekanika Tanah, Cetakan Ke-enam. Jakarta: Badan Penerbit Pekerjaan umum.

Wesley, L.D. (2012). Mekanika Tanah Untuk Tanah Endapan dan Residu. Yogyakarta: Penerbit ANDI.

Yang Fang. H. (1991). Foundation Engineering Handbook.

Amerika: Kluwer Academic Publisher.

Yuliet Rina, A., et. al. (2011). Uji potensi mengembang pada tanah lempung dengan metoda free swelling test (Studi Kasus: Tanah Lempung Limau Manih Kota Padang). Jurnal Rekayasa Sipil, 7(1), Februari 2011, 25-36. 